\title{
Calcareous nannofossils from the Bathonian (Middle Jurassic) ore-bearing clays at Gnaszyn as palaeoenviron- mental indicator, Kraków-Silesia Homocline, Poland
}

\author{
MARIUSZ KĘDZIERSKI \\ Institute of Geological Sciences, Jagiellonian University, Oleandry Str. 2a, 30-063 Kraków. \\ E-mail:mariusz.kedzierski@uj.edu.pl
}

\begin{abstract}
:
Kedzierski, M. 2012. Calcareous nannofossils from the Bathonian (Middle Jurassic) ore-bearing clays at Gnaszyn as palaeoenvironmental indicator, Kraków-Silesia Homocline, Poland. Acta Geologica Polonica, 62 (3), 421-437. Warszawa.

Qualitative and quantitative studies on calcareous nannofossils have been carried out on the Middle-Upper Bathonian succession of Gnaszyn (Kraków-Silesia Homocline, Częstochowa region). The nannofossil assemblages are moderately or well-preserved and are dominated by Watznaueria britannica; also common are Staurolithites lumina and Zeugrhabdotus erectus. The presence of delicate nannofossil forms together with dissolution-resistant taxa shows that the changes in composition of some of the nannoplankton assemblages reflect original variations. The frequency and diversity changes of the calcareous nannofossil assemblages have been interpreted in relation to fluctuations of sedimentation rate versus changes in trophic conditions within the photic zone. The highest diversity assemblages contain a high percentage of palaeofertility indicators, and are impoverished in the genus Watznaueria. This is interpreted as a reflection of a lower sedimentation rate and more stable, possibly mesotrophic conditions within the photic zone. On the other hand, W. britannica-dominated assemblages with low species diversity may represent more unstable environments with a high influx of terrestrial material related to a high sedimentation rate and a high nutrient influx, i.e. eutrophic conditions in the photic zone.
\end{abstract}

Key words: Bathonian; Jurassic; Calcareous nannofossils; Palaeoenvironment; KrakówSilesia Homocline; Poland.

\section{INTRODUCTION}

The oldest nannofossils have been reported from the Late Triassic and are known only from shallowmarine, low-palaeolatitude environments, mainly from the Tethys (Bown 1987). During the Early Jurassic, nannofossils expanded from the shallow Tethyan seas to other environments and underwent great taxonomic diversification, with the maximum diversity achieved during the Early Toarcian (Roth 1986; Bown et al. 1992, 2004; Bown and Young 1998a). Since that time, due to biocalcification, nannoplankton started to be the major primary producer of carbonates in oceanic realms. It has been responsible for the production of huge amounts of carbonates at least since the Early Cretaceous (Burnett et al. 2000; Rost and Riebesell 2004; Less et al. 2005). The nannoplankton ooze production in the oceanic pelagic zones may be considered the most important indicator of the primary surface water productivity since the Middle/Late Jurassic (Roth 1986; Brummer and van Eijden 1992). It also influenced the climate during the MesozoicCenozoic with both positive and negative feedbacks (Burnett et al. 2000). Moreover, it is believed that 
changes of climate influenced the nannoplankton phylogeny and its environmental adaptations. For example, cooling in the Mesozoic greenhouse caused diversification of calcareous nannoplankton and thus palaeolatitudinal differentiation (Bown et al. 2004).

The recognition of the environmental preferences of the nannoplankton is one of the main goals in recent studies on both extant and extinct assemblages. After preliminary agreement concerning the palaeoenvironmental preferences of particular taxa, it has been concluded that palaeoenvironmental interpretations based solely on nannoplankton are strongly biased. Moreover, analogies based directly on modern assemblages could have led to erroneous results, since the Creta-
ceous/Paleogene boundary extinction eliminated $\mathrm{c}$. $93 \%$ of the species and there are no extant forms representing the main Mesozoic taxa (for discussion see Lees et al. 2005). Nevertheless, the latitude, surface oceanic water-currents, and temperature (e.g., Okada and Honjo 1973), as well as nutrient supply (e.g., Lampert et al. 2002; Andruleit et al. 2003), are considered the main factors controlling the distribution of modern and, by analogy, also the extinct nannoplankton (see also Lees et al. 2005).

The main purpose of this paper is the interpretation of the palaeoenvironment of the Bathonian clays in Gnaszyn, based on calcareous nannofossil assemblages and their dynamics.
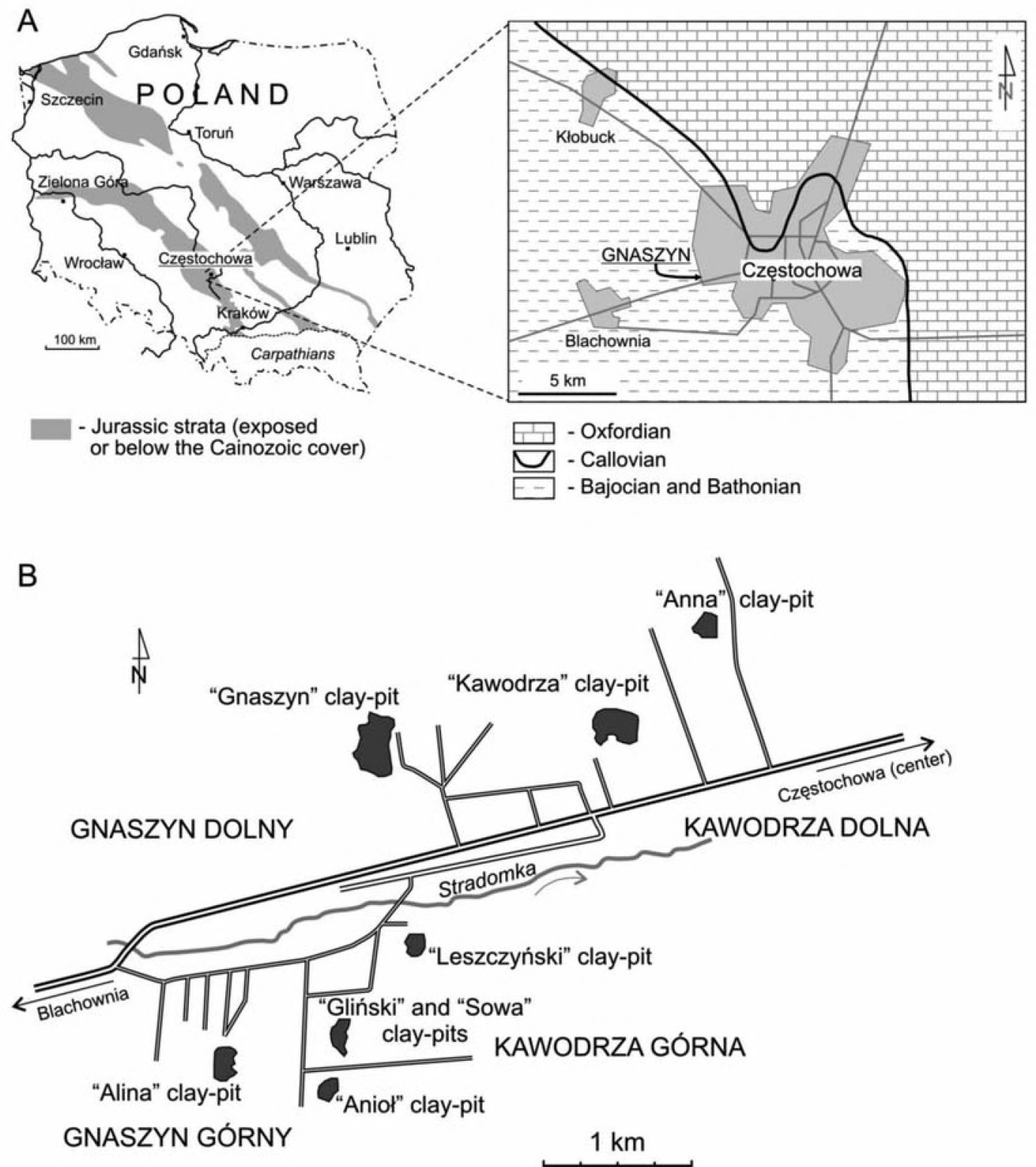
CALCAREOUS NANNOFOSSILS FROM MIDDLE JURASSIC ORE-BEARING CLAYS

\section{GEOLOGICAL SETTING}

The Gnaszyn section is located in the western part of the town of Częstochowa (Central Poland) (Textfig. 1). It is an active clay-pit, exposing a monotonous series of soft clays or clayey shales, black or dark grey in colour. The clays are strongly bioturbated with the primary lamination rarely observed (Leonowicz 2012, this issue). They are partially enriched in coarsegrained clasts, especially in the lower and upper parts of the succession. Distinctive horizons of large siderite concretions with common septarian structures (Majewski 2000; Witkowska 2012, this issue; Text-fig. 2) are scattered throughout the succession.

The Gnaszyn succession represents the offshore zone below the fair-weather wave base, commonly af- fected by storms and river input (Leonowicz 2012, this issue), rich in both benthic and nektonic macrofauna and plant fossils. The most common are bivalves, gastropods, cnidarians and ammonites (see also Majewski 2000; Gedl et al. 2003; Matyja and Wierzbowski 2003; Kaim 2004, 2008, 2011).

The calcareous nannoplankton was studied from sections A, B and C (Text-fig. 2). Sections A and B represent the Middle-Upper Bathonian Subcontractus through Retrocostatum ammonite zones. Section C represents the Upper Bathonian Retrocostatum Ammonite Zone (Gedl and Kaim 2012, this issue). In the nannoplankton scheme, the succession represents the NJ 11 Pseudoconus enigma Biozone, which spans most of the Bathonian, from the Parkinsoni up to the Hodsoni ammonite biozones (Bown and Cooper 1998).

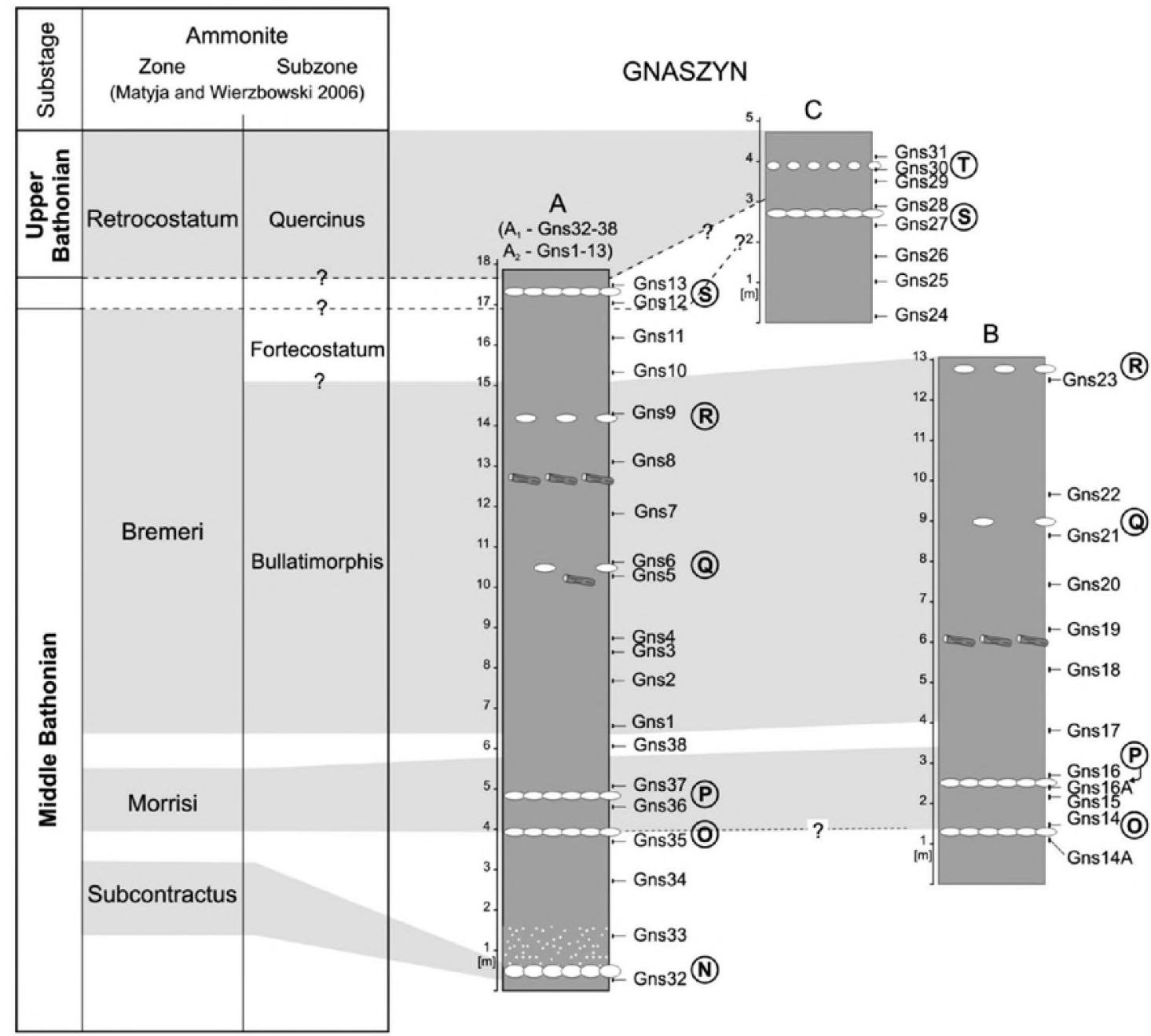

- Gns32 - sample location $\quad 0000$ - siderite concretion level - sunken driftwood level

(N) - abbreviation of concretion level 


\section{MATERIAL AND METHODS}

Forty rock samples were studied (Text-fig. 2). The light microscope slides were prepared using the simple smear-slide method; a small amount of rock-sample was scraped onto the slide and spread across its surface with a little water; after drying, the slide was covered with a cover-glass with a drop of Canadian Balsam (see also Bown and Young 1998b). The slides were then inspected under the polarised light microscope Nikon Eclipse 600 under cross polarised light or phase contrast at magnification $\times 1000$. The relative nannofossil abundance was determined based on c. 300 specimens calculated on a smear-slide (Thierstein et al. 1977; Bown and Young 1998b). In samples with total nannofossil abundance below 300 , the percentage was computed based on 200 specimens available for analysis. The approximate abundance of nannofossil assemblages within a slide was measured as a mean content of specimens (of all taxa) per field(s) of view (abbreviated FOV). Three categories of abundance were distinguished: very rare -1 specimen per $10 \mathrm{FOVs}$ or less; rare -1 specimen per $1-9$ FOVs; frequent - 1 specimen per 1 FOV; common - 2 - 10 specimens per 1 FOV. The nannofossil state of preservation was estimated using the scale of Roth (1983) where E (weak E-1 to strong E-3) means the level of etching by dissolution; and $\mathrm{O}$ (weak $\mathrm{O}-1$ to strong $\mathrm{O}-$ 3) means secondary calcite overgrowth; $X$ means excellent state of preservation.

\section{RESULTS}

Calcareous nannofossils, of moderate to poor preservation (E-2, on average), were found in all investigated samples. The samples with a coarse-
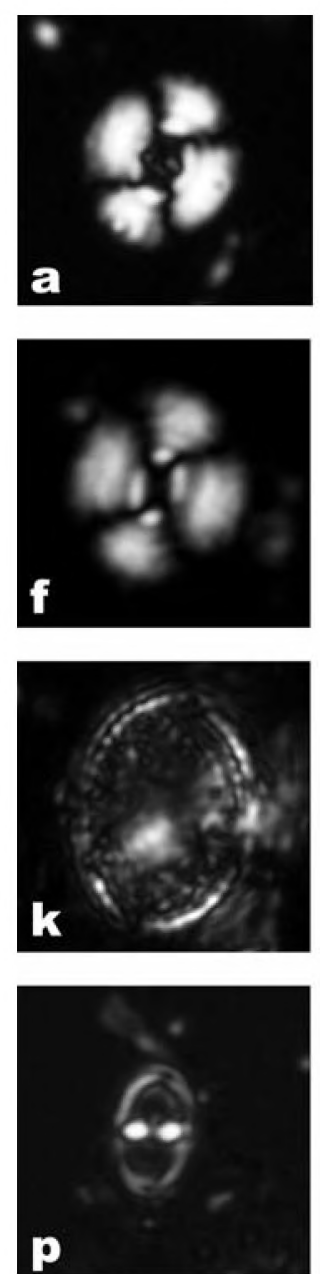
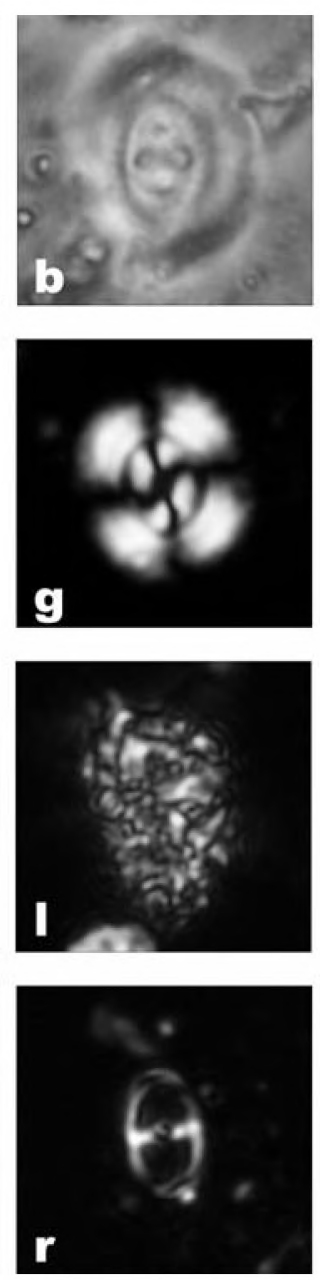
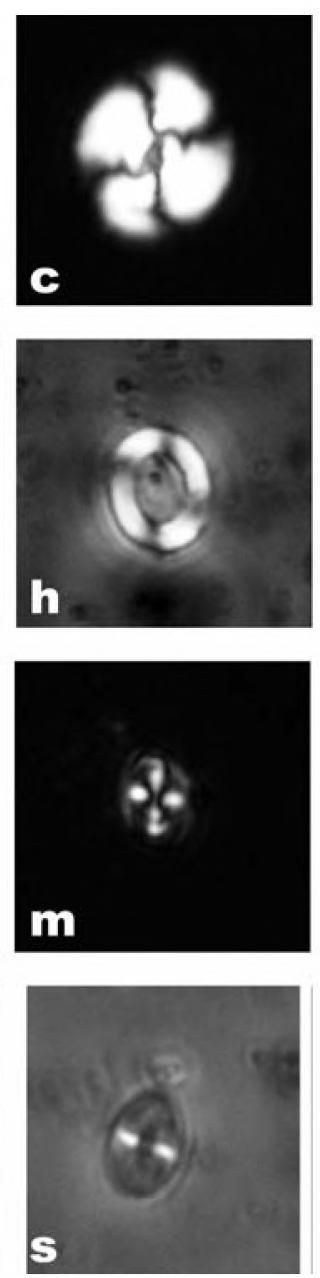
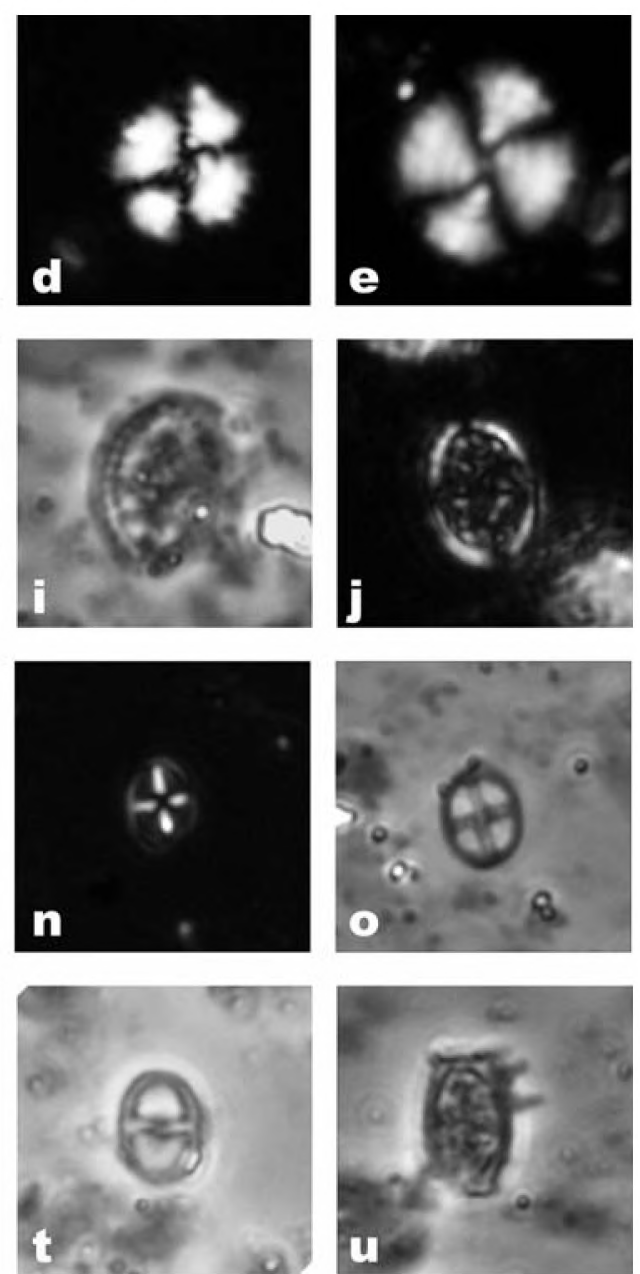

Text-fig. 3. Calcareous nannoplankton Gmaszyn (BF - bright field; XPL - cross polarised light; PC - phase contrast). a - Watznaueria britannica XPL, Gns30. b - W. britannica PC, Gns36. c, d-W. bamesiae XPL, Gns30. e - W. cf. W. barnesiae XPL, Gns36. f, g - W. fossacincta XPL, Gns36. h - W. cf. W. ovata PC, Gns36. i - Octopodorhabdus decussatus PC, Gns36. j- O. decussatus Gns36, XPL. k - Ethmorhabdus gallicus XPL, Gns36. 1 - Pseudoconus cf. P. enigma XPL, Gns14A. m, nStaurolithites himina XPL, Gns30. o-S. lumina BF, Gns36. p, $\mathbf{r}-$ Zeugrhabdotus erectus XPL, Gns30. s, $\mathrm{t}-$ Z. erectus PC, Gns36. $\mathbf{u}-$ Stephanolithion speciosum PC, Gns11. 
grained organic matter fraction contain etched and/or broken nannofossils, with E-3 state of preservation. The better preserved assemblages (mainly E-2, but also E-1) contain some coccospheres. In the middle parts of sections $A$ and $B$, and in the lower part of section $\mathrm{A}$, calcareous nannoplankton is very rare or rare; 1 specimen per 10 FOV or less. Calcareous nannoplankton is more abundant (few to common) in the lower part of section B and in the uppermost parts of sections $\mathrm{A}$ and $\mathrm{C}$.

Thirty-eight species-level taxa (with some left in open nomenclature) have been recognised (Table 1, Textfig. 3), with their richness varying between 5 (Gns4, 32) and 22 (Gns9) per sample. The lowest richness is observed in the lower parts of sections $A(G n s 32,35)$ and B (Gns16A, 16). Higher up the succession the richness gradually increases, although some exceptions are noticed (samples Gns35 to Gns4 in section A; or samples Gns20 and 21 in section B). As expected, the richness strongly correlates with sample size (Text-figs 4, 5).

The most common is genus Watznaueria, attaining a mean contribution to the calcareous nannofossil assemblages of c. $80 \%$, reaching up to $97 \%$ of the total abundance in sample Gns4. This genus is represented mainly by $W$. britannica, which dominates all samples. The percentage of this species is the highest in the middle part of section $A$ and in the lower and upper parts of section B (Gns3, 4 and Gns14, 21). Also common are $W$. fossacincta (26\% in Gns5) and W. barnesiae ( $41 \%$ in sample Gns36). The former is also more abundant in the middle part of the studied sections (Gns1, 5 and Gns19). The latter is the most abundant in the lower part of section A (Gns33, 36) and in the basal sample, Gns14A, of section B (Text-figs 4, 5).

Also common is Staurolithites lumina. It occurs in all samples, except Gns33, with relative abundance ranging from $1.3 \%$ (Gns32 and 14A) to $33.9 \%$ (Gns29) and mean abundance $8 \%$ (Text-figs 4,5 ).

Zeugrhabdotus erectus occurs in abundances up to almost $11 \%$ (Gns29, 31). It is missing from several samples, particularly in the middle part of section $A$ and in the lowermost part of section $B$ (Tect-figs 4, 5). Its highest abundance was noticed in the upper part of section $\mathrm{C}$ and in the topmost part of section A (Text-figs 4, 5).

Biscutum dubium is also quite common, reaching $7.2 \%$ and $8.4 \%$ in samples Gns 22 and 28 respectively; it is absent in the lower part of section $B$, and in the lower and middle parts of section A.

Pseudoconus enigma, Ethmorhabdus gallicus, and Stephanolithion spp. (represented mainly by S. speciosum) have been found in particular samples at percentages higher than $2 \%$. However, their non-continuous occurrence (absence in some samples) remains statistically insignificant for the present analysis.

Percentages of the taxa mentioned above in relation to the calcareous nannoplankton assemblages are plotted against the lithological logs in Text-figs 4 and 5 .

Based on abundance of the taxa in the studied assemblages, a cluster analysis and linear regression for selected pairs of variables has been performed, using the PAST software (Hammer et al. 2001). For the statistics, four additional variables were plotted: abundances of: (1) Watznaueria spp.; (2) W. barnesiae $+W$. fossacincta; (3) Z. erectus $+B$. dubium + S. lumina, and

\begin{tabular}{|c|c|c|c|c|c|c|c|c|c|c|c|c|c|c|c|c|c|c|c|c|}
\hline Samples (Section A) & 32 & 33 & 34 & 35 & 36 & 37 & 38 & 1 & 2 & 3 & 4 & 5 & 6 & 7 & 8 & 9 & 10 & 11 & 12 & 13 \\
\hline Taxa richness per sample & 5 & 6 & 9 & 5 & 9 & 7 & 8 & 9 & 9 & 7 & 5 & 7 & 9 & 7 & 11 & 12 & 11 & 10 & 13 & 17 \\
\hline Anfractus harrisonii & 0 & 0 & 0 & 0 & 0 & 0 & 0 & 0 & 0 & 0 & 0 & 0 & 0.395 & 0 & 0 & 0 & 0 & 0 & 0.412 & 2.007 \\
\hline Axopodorhabdus cylindratus & 0 & 0 & 0 & 0 & 0 & 0 & 0 & 0 & 0 & 0 & 0 & 0 & 0 & 0 & 0 & 0 & 0 & 0 & 0.823 & 0 \\
\hline Axopodorhabdus atarus & 0 & 0 & 0 & 0 & 0 & 0 & 0 & 0 & 0 & 0 & 0 & 0 & 0 & 0 & 0 & 0 & 0 & 0 & 0 & 0.334 \\
\hline Axopodorhabdiss sp. & 0 & 1.852 & 2.941 & 0 & 1.835 & 1.031 & 1.13 & 0 & 0 & 0 & 0 & 0.478 & 0 & 0 & 0.749 & 0 & 0 & 0 & 0 & 0 \\
\hline Biscutum dubium & 0 & 0 & 2.941 & 0 & 1.835 & 0 & 1.695 & 1.622 & 1.212 & 0.877 & 1.117 & 0 & 0.791 & 0 & 2.622 & 0.735 & 2.381 & 0.816 & 1.646 & 2.676 \\
\hline Biscutum finchii & 0 & 0 & 1.471 & 0 & 0 & 0 & 0 & 0 & 0 & 0 & 0 & 0 & 0 & 0 & 0 & 0 & 0 & 0 & 0 & 0 \\
\hline Biscutum sp. & 1.299 & 0 & 0 & 0 & 0 & 0 & 0 & 0 & 3,03 & 0 & 0 & 0 & 0 & 0 & 0 & 0 & 0 & 0 & 0 & 1.672 \\
\hline Cribrosphaerella ehrenbergii & 0 & 0 & 0 & 0 & 0 & 0 & 0 & 0 & 0 & 0 & 0 & 0 & 0 & 0 & 0 & 0.368 & 0 & 0 & 0 & 0 \\
\hline Cyclagelosphaera margarelii & 0 & 0 & 0 & 0 & 0 & 0 & 0 & 0 & 0 & 0 & 0 & 0 & 0 & 0 & 0.375 & 0 & 0 & 0 & 0 & 0 \\
\hline Ethmorhabdus gallicus & 0 & 0 & 0 & 2.222 & 1.835 & 0 & 0 & 0 & 0 & 0 & 0 & 0 & 0 & 0 & 0 & 0.735 & 0.397 & 0 & 0.412 & 0.334 \\
\hline Lotharingitus sigillatus & 0 & 1.852 & 0 & 0 & 0 & 0 & 0 & 0.541 & 3.636 & 1.754 & 0 & 0 & 1.186 & 0.69 & 1.873 & 0.368 & 0.794 & 0 & 0.823 & 1.338 \\
\hline Lotharingius sp. & 0 & 0 & 1.471 & 0 & 1.835 & 1.031 & 1.13 & 0.541 & 0 & 0 & 0 & 0.957 & 0 & 1.379 & 0 & 0.735 & 0.397 & 0.408 & 0 & 2.341 \\
\hline Parhabdolithus sp. & 0 & 0 & 0 & 0 & 0 & 0 & 0 & 0 & 0 & 0 & 0 & 0 & 0 & 0 & 0 & 0 & 0 & 0 & 0 & 0.669 \\
\hline Polypodorhabdus escaigii & 0 & 0 & 0 & 0 & 0 & 0 & 0 & 0 & 0 & 0 & 0 & 0 & 0 & 0 & 0 & 0 & 0.794 & 1.224 & 0 & 0 \\
\hline Podorhabdus grassei & 0 & 0 & 0 & 0 & 0 & 0 & 0 & 0 & 0 & 0 & 0 & 0 & 0 & 0 & 0 & 0 & 0 & 0 & 0 & 0.334 \\
\hline Pseudoconus enigma & 1.299 & 1.852 & 4.412 & 3.333 & 0 & 3.093 & 0 & 0 & 3.636 & 0.439 & 0.559 & 0 & 0.791 & 0,69 & 0,749 & 0 & 2.381 & 0.408 & 1.235 & 0.669 \\
\hline Stephanolithion speciosum & 0 & 0 & 0 & 0 & 0 & 0 & 0.565 & 0 & 0 & 0 & 0 & 0 & 0 & 0 & 0 & 0 & 0 & 1.633 & 0.823 & 0.334 \\
\hline Stephanolithion sp. & 0 & 0 & 0 & 0 & 0 & 0 & 0 & 0.541 & 0 & 0 & 0 & 0 & 0 & 0 & 0 & 0 & 0 & 0 & 0 & 0 \\
\hline Staurolithites lumina & 1.299 & 0 & 4.412 & 3.333 & 7.339 & 7.216 & 28.25 & 11.35 & 6.667 & 1.754 & 1.676 & 8.612 & 1.976 & 2.759 & 4.12 & 2.574 & 5.556 & 12.24 & 4.115 & 13.38 \\
\hline Tetrapodorhabdus shawensis & 0 & 0 & 0 & 0 & 0 & 0 & 0 & 0 & 0 & 0 & 0 & 0 & 0 & 0 & 0.749 & 0.735 & 0 & 0 & 0 & 0 \\
\hline Tetrapodorhabdus sp. & 0 & 0 & 0 & 0 & 0 & 0 & 0 & & 0 & 0 & 0 & 0 & 0 & 0 & 0 & 0 & 0 & 0 & 0 & 0.334 \\
\hline Triscutum sp. & 0 & 0 & 0 & 0 & 0 & 0 & 0 & 0.541 & 0 & 0 & 0 & 0 & 0 & 0 & 0 & 0 & 0 & 0 & 0 & 0 \\
\hline Tubirhabdus patulus & 0 & 0 & 0 & 0 & 0 & 0 & 0 & 0 & 0 & 0 & 0 & 0 & 0 & 0 & 0 & 0.368 & 0 & 0 & 0.412 & \\
\hline Watznaueria barnesiae & 31.17 & 37.04 & 13.24 & 33.33 & 41.28 & 17.53 & 6.78 & 10.81 & 1.818 & 3.07 & 0 & 1.435 & 0 & 0.69 & 1.873 & 1.838 & 0.794 & 0 & 2.469 & 5.017 \\
\hline Watznaueria britannica & 64.94 & 55.56 & 58.82 & 57.78 & 41.28 & 51.55 & 56.5 & 49.19 & 60.61 & 74.56 & 83.8 & 62.2 & 79.05 & 82.76 & 71.16 & 82.35 & 75.4 & 65.31 & 65.84 & 43.48 \\
\hline Watznatueria fossacincta & 0 & & 2.941 & 0 & 1.835 & 17.53 & 0 & 24.86 & 18.79 & 17.54 & 12.85 & 25.84 & 15.81 & 11.03 & 14.98 & 7.353 & 7.937 & 16.33 & 20.58 & 16.72 \\
\hline Zeugrhabdotus erectus & 0 & 1.852 & 7.353 & 0 & 0.917 & 1.031 & 3.955 & 0 & 0.606 & 0 & 0 & 0.478 & 0 & 0 & 0.749 & 1.838 & 3.175 & 1.633 & 0.412 & 8.361 \\
\hline
\end{tabular}

Table 1a. Sample taxon-richness and relative abundance of taxa and calcareous nannoplankton abundance 


\begin{tabular}{|c|c|c|c|c|c|c|c|c|c|c|c|c|}
\hline Samples (Section B) & 14A & 14 & 15 & $16 \mathrm{~A}$ & 16 & 17 & 18 & 19 & 20 & 21 & 22 & 23 \\
\hline Taxa richness per sample & 10 & 10 & 9 & 6 & 7 & 9 & 16 & 16 & 15 & 10 & 14 & 15 \\
\hline Anfractus harrisonii & 0 & 0 & 0 & 0 & 0 & 0 & 0 & 0,671 & 0 & 0,498 & 0,578 & 0 \\
\hline Axopodorhabdus cylindratus & 0 & 0,424 & 0 & 0 & 0 & 0 & 0,338 & 0,336 & 0,352 & 0 & 0 & 0 \\
\hline Axopodorhabdus sp. & 0,667 & 0 & 1,158 & 0 & 0 & 0,402 & 0 & 0 & 0 & 0 & 0 & 0,333 \\
\hline Biscuttom dubium & 0 & 0 & 0 & 2,985 & 0 & 1,606 & 1,351 & 4,362 & 4,225 & 0,498 & 7,225 & 2 \\
\hline Biscutum finchii & 0 & 0 & 0 & 1,493 & 0 & 0 & 0 & 0 & 0 & 0 & 0 & 0 \\
\hline Biscuttum sp. & 0 & 0 & 0 & 0 & 0 & 0,402 & 0,676 & 0 & 0 & 0 & 0 & 0 \\
\hline Cretarhabdus cf. conicus & 0 & 0 & 0 & 0 & 0,704 & 0 & 0 & 0 & 0 & 0 & 0 & 0 \\
\hline Cyclagelosphaera margarelii & 0 & 0,424 & 0 & 0 & 0 & 0 & 0,338 & 0 & 0 & 0 & 0 & 0 \\
\hline Ethmorhabdus gallicus & 0 & 0 & 1,931 & 0 & 0 & 0 & 0,338 & 1,678 & 1,408 & 0,995 & 0,867 & 0,667 \\
\hline Hexapodorhabdus sp. & 0 & 0 & 0 & 0 & 0 & 0 & 0,338 & 0 & 0 & 0 & 0 & 0 \\
\hline Lotharingius hauffi & 0 & 0 & 0 & 0 & 0 & 0 & 0 & 0 & 0 & 0 & 0 & 0,333 \\
\hline Lotharingitus sigillatus & 0 & 0 & 0 & 0 & 0 & 2,008 & 0,338 & 2,349 & 0,704 & 2,488 & 0 & 1,667 \\
\hline Lotharingius sp. & 1,333 & 1,271 & 0 & 0 & 0,704 & 0 & 0,338 & 0,336 & 1,056 & 0 & 0,867 & 1 \\
\hline Polypodorhabdus escaigii & 0 & 0,424 & 0 & 0 & 0 & 0,402 & 0,676 & 0 & 1,056 & 0,498 & 0,867 & 0 \\
\hline Pseudoconus enigma & 6,667 & 4,237 & 0,772 & 1,493 & 2,113 & 0,803 & 1,014 & 1,007 & 1,056 & 0,498 & 0,867 & 1 \\
\hline Retecapsa sp. & 0 & 0 & 0 & 0 & 0 & 0 & 0 & 0,336 & 0 & 0 & 0 & 0 \\
\hline Staurolithites lumina & 1,333 & 3,814 & 3,475 & 4,478 & 4,93 & 22,09 & 11,82 & 11,74 & 12,32 & 8,955 & 18,79 & 10 \\
\hline Stephanolithion speciosum & 0,667 & 0 & 0 & 0 & 0 & 0 & 0,338 & 0,671 & 0,352 & 0 & 0,289 & 0,333 \\
\hline Tetrapodorhabdus shawensis & 0 & 0 & 0,772 & 0 & 0 & 0 & 0 & 0,336 & 0 & 0 & 0,289 & 0,667 \\
\hline Tetrapodorhabdus sp. & 0 & 0 & 0 & 0 & 0 & 0 & 0 & 0 & 0,352 & 0 & 0 & 0 \\
\hline Triscutum sp. & 0 & 0 & 0 & 0 & 0 & 0 & 0 & 0 & 0 & 0 & 0,867 & 0,667 \\
\hline Tubirhabdus patulus & 0,667 & 0 & 0 & 0 & 0 & 0 & 0 & 0,336 & 0 & 0 & 0 & 0 \\
\hline Watznateria bamesiae & 30 & 1,271 & 4,633 & 11,94 & 2,113 & 0 & 3,041 & 2,685 & 0,704 & 0 & 0 & 1,667 \\
\hline Watznateria britannica & 41,33 & 85,17 & 69,5 & 77,61 & 77,46 & 60,24 & 67,57 & 48,99 & 70,42 & 79,6 & 57,8 & 76,67 \\
\hline Watznatueria fossacincta & 16,67 & 2,966 & 17,37 & 0 & 11,97 & 12,05 & 11,15 & 21,48 & 4,225 & 4,975 & 8,96 & 2 \\
\hline Zeugrhabdotus erecius & 0,667 & 0 & 0,386 & 0 & 0 & 0 & 0,338 & 2,685 & 1,761 & 0,995 & 1,734 & 1 \\
\hline
\end{tabular}

Table 1b. Sample taxon-richness and relative abundance of taxa and calcareous nannoplankton abundance

\begin{tabular}{|c|c|c|c|c|c|c|c|c|}
\hline Samples (Section C) & 24 & 25 & 26 & 27 & 28 & 29 & 30 & 31 \\
\hline Taxa richness per sample & 13 & 13 & 18 & 15 & 16 & 22 & 18 & 16 \\
\hline Anfractus harrisonii & 0 & 0 & 0,73 & 0,669 & 0 & 0 & 0,336 & 1,083 \\
\hline Axopodorhabdus cylindratus & 0,324 & 0,42 & 0 & 0,669 & 0 & 0,424 & 0 & 0 \\
\hline Axopodorhabdus sp. & 0 & 0 & 0 & 0 & 0,669 & 0,424 & 0,671 & 0 \\
\hline Biscutum dubium & 4,854 & 2,101 & 3,285 & 4,682 & 8,361 & 5,085 & 3,02 & 3,249 \\
\hline Biscutum finchii & 0 & 0 & 0 & 0 & 0 & 0,847 & 0 & 0 \\
\hline Biscutum sp. & 0 & 0,42 & 0 & 0 & 0 & 0,424 & 0 & 0 \\
\hline Calyculus sp. & 0 & 0 & 0,365 & 0 & 0 & 0 & 0 & 0 \\
\hline Cretarhabdus cf. conicus & 0 & 0 & 0 & 0 & 0 & 0,424 & 0 & 0 \\
\hline Cribrosphaerella ehrenbergii & 0 & 0 & 0 & 0 & 0 & 0 & 0 & 0,361 \\
\hline Cyclagelosphaera margarelii & 0 & 0 & 0 & 1,003 & 0 & 0 & 0,336 & 0 \\
\hline Ethmorhabdus gallicus & 0,324 & 0,42 & 1,095 & 0,669 & 0,669 & 0,847 & 0,671 & 0,722 \\
\hline Hexapodorhabdus cuvillieri & 0 & 0 & 0,365 & 0 & 0 & 0 & 0 & 0 \\
\hline Hexapodorhabd & 0 & 0 & 0 & 0 & 0 & 0,424 & 0 & 0 \\
\hline Lotha & 0 & 0 & 0,365 & 0 & 0 & 0 & 0 & 0 \\
\hline Lotharingius sigillatus & 2,913 & 0 & 1,825 & 1,338 & 1,338 & 0,847 & 1,342 & 1,444 \\
\hline Lotharingius sp. & 1,942 & 2,101 & 2,19 & 0,334 & 3,679 & 1,271 & 2,013 & 3,249 \\
\hline Octopodorhabdus decussatus & 0 & 0 & 0 & 0 & 0 & 0,424 & 0 & 0,361 \\
\hline Polypodorhabdus escaigii & 0,647 & 0,42 & 0 & 1,672 & 1,338 & 0,847 & 0,336 & 0,361 \\
\hline Podorhabdus grassei & 0 & 0 & 0 & 0 & 0 & 0 & 0 & 0 \\
\hline Pseudoconus enigma & 0 & 0 & 0,365 & 1,672 & 0,334 & 0 & 0,336 & 0,361 \\
\hline Rete & 0 & 0 & 0 & 0 & 0 & 0,424 & & 0 \\
\hline Scht & & 0 & 0,365 & 0 & 0 & 0 & 0 & 0 \\
\hline Staurolithites lumina & 16,83 & 23,95 & 18,25 & 12,37 & 20,4 & 33,9 & 20,13 & 14,44 \\
\hline Stephanolithion hexum & & 0 & 0 & 0 & 0 & 0 & 0,671 & 0 \\
\hline Stephanolithion speciosum & 0,647 & 0,42 & 0,73 & 1,003 & 1,672 & 2,119 & 0 & 1,444 \\
\hline Stradnelithus sp. & & 0 & 0 & 0 & 0,334 & 0 & 0 & 0 \\
\hline Tetrapodorhabdus shawensis & 0,647 & 0,84 & 0,73 & 0 & 0,334 & 0 & 0,336 & 0,361 \\
\hline Tetrapodorhabdus sp. & 0 & 0 & 0 & 0 & 0 & 0 & 0,336 & 0 \\
\hline Triscutum cf. sullivanit & 0 & 0 & 0,73 & 0 & 0 & & 0 & 0 \\
\hline & 0 & 0,42 & 0 & 0 & 0 & 0,424 & 0,671 & 0 \\
\hline Tubirhabdus patulus & 0 & 0 & 0 & 0 & 0,669 & 0,847 & 0 & 0 \\
\hline Watznaueria barnesiae & 1,942 & 0 & 0,73 & 4,013 & 0,334 & 4,661 & 1,342 & 1,444 \\
\hline nateria britannica & 55,02 & 63,03 & 51,09 & 54,52 & 41,47 & 21,19 & 53,69 & 50,54 \\
\hline Watznaueria fossacincta & 9,061 & 2,101 & 8,394 & 9,03 & 10,03 & 13,14 & 8,054 & 9,747 \\
\hline Zeugrhabdotus erectus & 4,854 & 3,361 & 8,394 & 6,355 & 8,361 & 11,02 & 5,705 & 10,83 \\
\hline
\end{tabular}

Table 1c. Sample taxon-richness and relative abundance of taxa and calcareous nannoplankton abundance

(4) the number of taxa per slide. Variable (1) contains all the Watznaueria species, and variable (4) is the total sample taxonomic diversity. Tree cluster analysis shows four clusters (Text-fig. 6).

The linear regressions (described by the correlation coefficient $-\mathrm{R}$ ) have been plotted to determine the relationship between pairs of selected variables. Table 2 shows the $\mathrm{R}$ values for all the variables with relatively continuous occurrence through the succession, signifi- cant similarity by means of cluster analysis and mean percentage value above 2 . Most of the $R$ values show weak $(0.1=|R|<0.3)$ or average $(0.3=|R|<0.5)$ linear correlations between the variables. Some of the pairs are extremely weakly correlated by means of the linear regression $(0<|R|<0.1)$. Nevertheless, the most interesting are pairs with strong $(0.5=|\mathrm{R}|<0.7)$ and very strong $(0.7=|R|<0.9)$ correlation coefficients, which have been noticed, among others, for the fol- 
CALCAREOUS NANNOFOSSILS FROM MIDDLE JURASSIC ORE-BEARING CLAYS

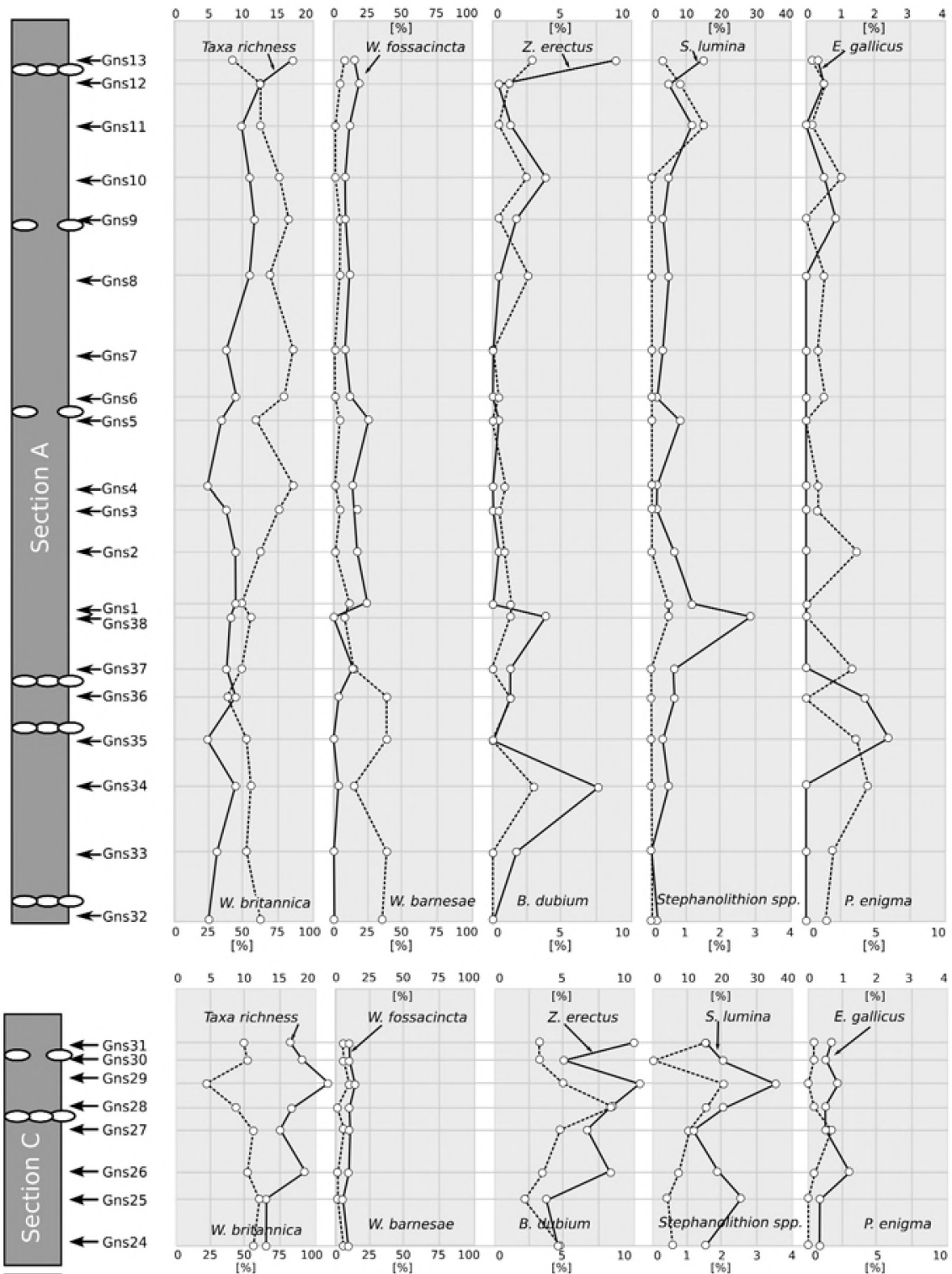

Text-fig. 4. Total richness and abundance of the most common calcareous nannoplankton taxa in section A
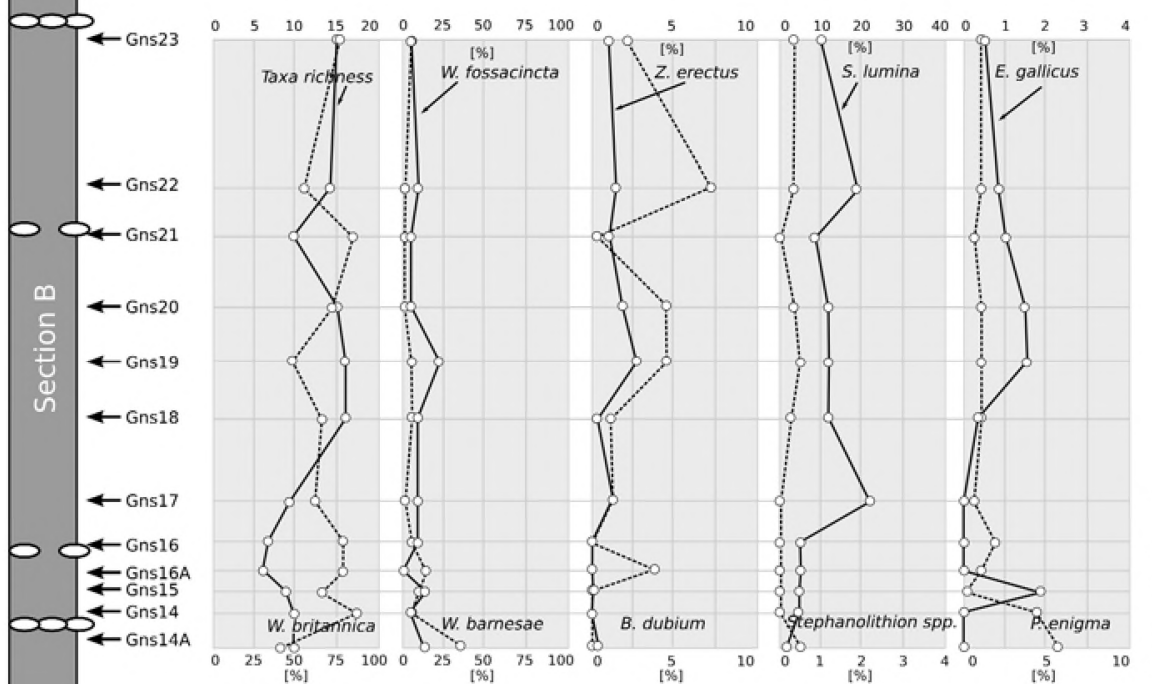

Text-fig. 5. Total richness and abundance of the most common calcareous nannoplankton taxa in sections $B$ and $C$ 
lowing pairs: Watznaueria spp. vs. Z. erectus $+B . d u-$ bium+S. lumina; Watznaueria spp. vs. S. lumina; Watznaueria spp. vs. Z. erectus; Watznaueria spp. vs. number of taxa; Watznaueria spp. vs. B. dubium; $Z$. erectus $+B$. dubium $+S$. lumina vs. number of taxa; $Z$. erectus vs. number of taxa. The rest of the strong or very strong linear fits can be omitted due to one of the variables being a part of the other variable in the pair, e.g. $S$. lumina is part of the $Z$. erectus $+B$. dubium $+S$. lumina variable, so the very strong linear fit for this pair is strongly affected by self-fitting. $R$ values taken into further considerations are shown in bold in Table 2 .

\section{DISCUSSION}

\section{Preservation}

Analysis of the sedimentary environment based on nannofossil assemblages first requires an estimation of the effects of the secondary (taphonomic) changes on the assemblages. Delicate nannoplankton forms, such as holococcoliths of simple rim-like structure, are the most susceptible to secondary processes. In contrast, the robust forms, like cubic nannoliths or placoliths with a solid central area, are the most resistant. One of the most resistant to dissolution among the placoliths are species of Watznaueria (Hill 1975; Thierstein 1980). Delicate forms, e.g., muroliths, Zeugrhabdotus spp. or Staurolithites spp., and placoliths, Biscutum spp., are relatively more fragile and they may easily be dissolved (Roth and Bowdler 1981). This can be observed well in sediments with high carbonate (dissolution and then recrystallisation effects) or high organic matter (dissolution effect) contents (see also Bown and Young 1998b). Consequently, assemblages dominated by the dissolu- tion-resistant taxa (e.g., Watznaueria) might be considered as strongly affected by diagenesis. Roth and Bowdler (1981) suggest that nannofossil assemblages composed of more than $40 \%$ of Watznaueria spp. may be regarded as strongly affected by diagenetic carbonate dissolution. However, this is not always the rule, and numerous, Watznaueria-rich assemblages may actually provide the primary environmental signal (e.g., Thomsen 1989). A good example was provided by Mattioli and Pittet (2002), based on early Jurassic limestonemarl alternations. They observed no significant difference in abundance of nannofossil assemblages between the marly and limestone parts of the cyclothems.

The state of preservation of the nannofossil assemblages is E-2 or E-3 (rarely E-1), what means that all of them were affected by dissolution. Nevertheless, the presence of delicate forms such as Staurolithites lumina, Biscutum dubium, Stephanolithion speciosum and Zeugrhabdotus erectus, indicates, that at least in some cases, the influence of diagenesis on the composition of the nannoplankton assemblages was insignificant.

\section{Calcareous nannofossils as a palaeoenvironmental indicator}

The coccolithophores producing the coccoliths belong to autotrophic microalgae (Billard and Inouye 2004). The light intensity, inorganic nutrients supply and other environmental factors (e.g., temperature or salinity) controlling the calcification and life processes of coccolithophores are similar to those preferred by other phytoplankton, including diatoms or dinoflagellates (Brand 1994). Coccolithophorids prefer low variability in N:P ratios in the upper $200 \mathrm{~m}$ of the water column, the shallower mixed layer depths, high surface ammonium concentrations, high N:Si ratios and low

\begin{tabular}{|c|c|c|c|c|c|c|c|c|c|}
\hline & $\begin{array}{l}\text { Taxa } \\
\text { richness }\end{array}$ & B. dubium & S. lumina & W. barnesiae & W. britannica & W. fossacincta & Z. erectus & Watznaueria spp. & $\begin{array}{l}\text { Z.erectus }+ \\
\text { B.dubium }+ \\
\text { S.lumina }\end{array}$ \\
\hline Taxa richness & 1 & & & & & & & & \\
\hline B. dubium & 0.673 & 1.000 & & & & & & & \\
\hline S. lumina & 0.647 & 0.603 & 1.000 & & & & & & \\
\hline W. barnesiae & -0.419 & -0.313 & -0.345 & 1.000 & & & & & \\
\hline W. britannica & -0.473 & -0.454 & -0.563 & -0.339 & 1.000 & & & & \\
\hline W. fossacincta & 0.082 & -0.065 & -0.066 & -0.338 & -0.156 & 1.000 & & & \\
\hline Z. erectus & 0.712 & 0.625 & 0.611 & -0.182 & -0.62 & -0.099 & 1.000 & & \\
\hline Watznaueria spp. & -0.796 & -0.767 & -0.907 & 0.292 & 0.684 & 0.085 & -0.850 & 1.000 & \\
\hline $\begin{array}{l}\text { Z. erectust } \\
\text { B. dubium }+ \\
\text { S. lumina } \\
\text { W. barnesiaet }\end{array}$ & 0.752 & 0.754 & 0.954 & -0.339 & -0.632 & -0.083 & 0.798 & -0.984 & 1.000 \\
\hline W. fossacinta & -0.371 & -0.359 & -0.391 & 0.793 & -0.444 & 0.305 & -0.248 & 0.350 & -0.397 \\
\hline
\end{tabular}


iron concentrations to grow and bloom (e.g., Lampert et al. 2002; Painter et al. 2010). Temperature and the accessibility of nutrients seem to have played the major role in controlling Mesozoic nannoplankton distribution (Burnett et al. 2000). The highest diversity assemblages of modern coccolithophores occur in subtropical oceanic gyres. Low-diversity assemblages with the highest total abundance are known from the subpolar or temperate regions (Winter et al. 1994). Such a pattern of distribution shows that the majority of modern coccolithophore species prefer moderately low turbulence, moderate nutrient supply, and moderate day-length (Brand 1994; Balch 2004). However, there are some modern species blooming in the fertile waters of coastal and/or equatorial upwellings. Emiliania huxleyi, in particular, is regarded as a typical eurytopic species that prefers meso- or eutrophic environments (Young 1994; Balch 2004). Similar ecological preferences are shown by other modern placolith-bearing coccolithophores (e.g., Gephyrocapsa), which occur in mass in environments with higher nutrient supply (high-mesotrophy to eutrophy) (e.g., Young 1994). These kinds of ecological preferences (among others: variable and uncertain climate, rapid development, and small body size) can be ascribed to $r$-selection (see Pianka 1970).

Species of Watznaueria, which dominated various Middle Jurassic and Cretaceous environments, are $r$-selected (e.g., Street and Bown 2000; Lees et al. 2004). Lees et al. (2004) interpreted Watznaueria fossacincta/W. barnesiae-dominated assemblages from the Upper Jurassic Kimmeridge Clay Formation (Dorset, UK), as nannoplankton blooms, representing the maximum stress of palaeoenvironmental condition. They found that the coccolith-bearing stone-band microlaminae in their studied succession recorded the seasonal blooms and peaks of eutrophy, while other non-watznaueriacean taxa were ecologically almost completely excluded. Subsequently, Lees et al. (2006) described an anomalously low-diversity assemblage dominated by Watznaueriaceae from the same formation, and interpreted it as the result of high trophic conditions that excluded most normal open-ocean taxa. They suggested that $W$. britannica was adapted to the highest nutrient concentration and therefore dominated in the lowest-diversity assemblages. Accordingly, the dominance of $W$. barnesiae/W. fossacincta in more diverse assemblages suggests their adaptation to slightly lower nutrient concentration. Cyclagelosphaera margerelii appears to be the most extreme r-selected species which may occurs in very high trophic conditions hostile even to $W$. britannica (Lees et al. 2006).

Giraud et al. (2009) recognised the spatial distribution of nannofossils in a Jurassic slope-to-basin tran- sect, which corresponds to a decrease in nutrient concentration, lower turbulence and an increase in environmental stability. Small-sized $W$. britannica dominated the low-diversity assemblages in the slope settings and became less dominant in the more diverse assemblages of the basinal settings, being replaced with $W$. barnesiae/ $W$. fossacincta. More detailed analysis of the influence of environmental conditions on morphology and abundance of $W$. britannica during the Late Jurassic was provided by Giraud et al. (2006). These authors concluded that low oligotrophic conditions in the surface water, connected with warm temperatures, were likely to be optimal for calcification of that species. Olivier et al. (2004) noted that small-sized $W$. britannica preferred high mesotrophic environments, $W$. barnesiae low-mesotrophic, whereas large-sized $W$. britannica and W. manivitae oligotrophic. Also Carcel et al. (2010) ascribed dominance of the smallest morphotype of $W$. britannica to higher trophic conditions, and similar results were reported by Pittet and Mattioli (2002), who concluded that $W$. britannica was more abundant in low-to-high mesotrophic conditions, whereas $W$. barnesiae and $W$. manivitae were more abundant in oligotrophic conditions. In contrast, the older results (e.g., Roth and Krumbach 1986; Herrle 2003) suggested that Watznaueria indicated low palaeofertility and/or pelagic palaeoenvironments (see also Perch-Nielsen 1985).

Generally, Watznaueria seems to be ubiquitous and dominant during the mid-Jurassic - Late Cretaceous, especially within the low and middle palaeolatitudes (e.g., Street and Bown 2000; Lees et al. 2004, 2005). The best proxy for the Mesozoic Watznaueria seems to be Emiliania huxleyi, one of the most opportunistic modern species (Lees et al. 2005).

Biscutum constans and Zeugrhabdotus spp. $(<5$ $\mu \mathrm{m})$ seem to have had a similar life strategy: their abundance usually increases in the upwelling zones and thus they may be regarded as good palaeofertility indicators (e.g., Roth and Bowdler 1981; Watkins 1989; Erba 1992; Street and Bown 2000). However, Giraud et al. (2009) and Giraud (2009) suggest that "these coccoliths were probably not competitive with respect to small-sized morphotypes of $W$. britannica in unstable and eutrophic surface waters for the Jurassic". On the other hand, Street and Bown (2000) noted that, although B. constans, Zeugrhabdotus sp. and Watznaueria barnesiae may have had a similar life strategy, their peaks of abundance are inverted. Abundances of $W$. barnesiae occur during periods of more muddy deposition while both B. constans and Zeugrhabdotus sp. are more common in more carbonate sediments. Despite the common use of these taxa as palaeofertility indicators neither 
their ecological relationships nor preferences are unequivocally clear (Lees et al. 2005).

\section{Cluster analysis}

Four clusters were revealed in the analysis, though only three of them may have significant similarity in terms of Euclidean distance (Text-fig. 6). The first cluster, of W. britannica and Watznaueria spp., has the highest similarity. However, as Watznaueria spp. consists mostly of $W$. britannica this cluster is almost $W$. britannica self-similarity. Similarly, the cluster grouping $W$. barnesiae and $W$. barnesiae $+W$. fossacincta. High similarity in this cluster is mainly $W$. barnesiae self-similarity. The third cluster groups S. lumina, number of taxa per slide, and $W$. fossacincta. This grouping suggests that $W$. fossacincta is a species of Watznaueria that is more abundant in more diverse assemblages, where other Watznaueria species become rare. It is noteworthy that $S$. lumina has the most continuous occurrence (absent in only one sample Gns33). This is the second species besides $W$. britannica with such a complete record, what may suggest their similar environmental preferences. S. lumina becomes more abundant when Watznaueria spp. becomes rarer. The fourth cluster, of $Z$. erectus and $B$. dubium, indicates similar trends in abundance changes. Based on cluster analysis it may be concluded that, among the Watznaueria

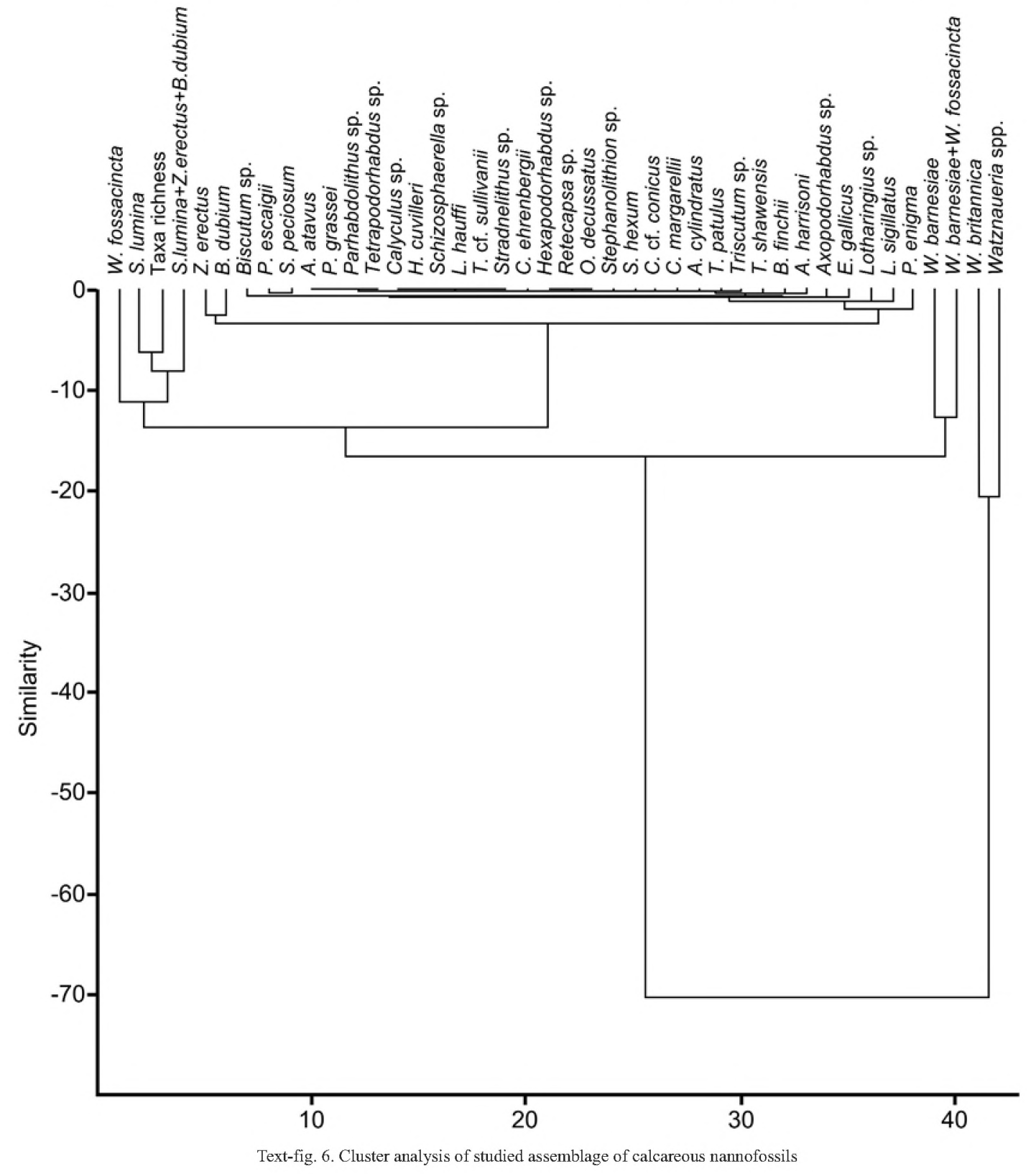


CALCAREOUS NANNOFOSSILS FROM MIDDLE JURASSIC ORE-BEARING CLAYS

species studied herein, $W$. fossacincta has a pattern of occurrence more similar to the group of $S$. lumina, $Z$. erectus and $B$. dubium than to other Watznaueria species.

\section{Interpretation of the correlation coefficient}

The abundances of $B$. dubium, S. lumina and $Z$. erectus are proportionally correlated with assemblages richness, with similar $\mathrm{R}$ value. There are, most probably, some differences in the abundances between these three taxa, because their sum has an even higher $\mathrm{R}$
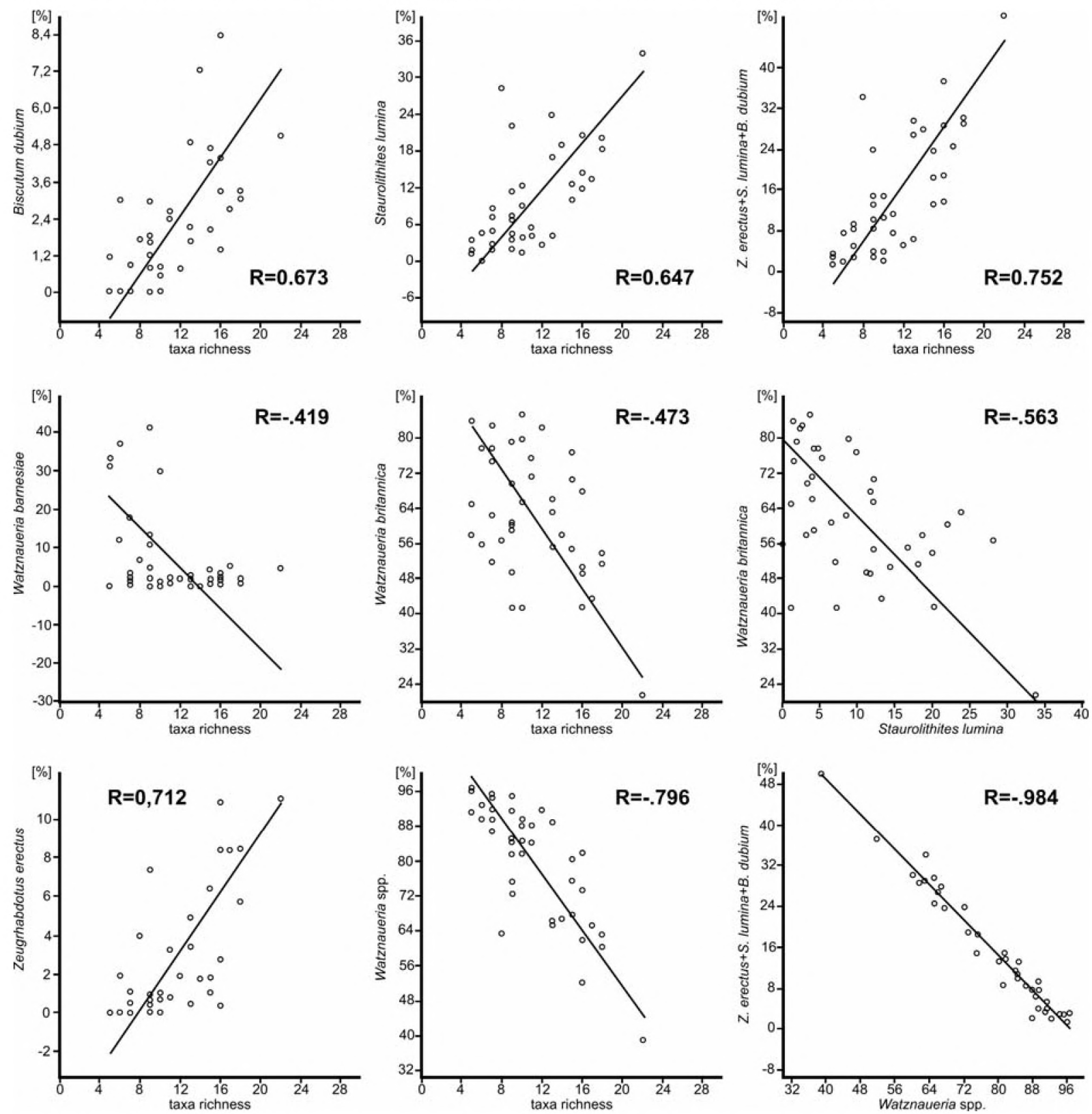

Text-fig. 7. Scatter diagrams plotted for selected pairs of variables. Section A is available in column on left side and sections B and C on right. Linear regressions are shown together with value of the correlation coefficient $(R)$ 
A high |R| value for Watznaueria spp. and significantly lower $|R|$ values for particular species of this genus suggest some shift in abundance between $W$. britannica and $W$. barnesiae, the most common species recorded in the samples. Their occurrences almost complement one another. Thus, they probably dominated in slightly different palaeoenvironmental conditions. This assumption is also supported by an average $|\mathrm{R}|$ value for that pair. $W$. fossacincta shows weak or no correlation in almost every pair of the variables. Also, W. barnesiae $+W$. fossacincta seems to have no significance for ecological considerations in term of correlation coefficient because its average $|\mathrm{R}|$ value is derived mainly from the $W$. barnesiae $|\mathrm{R}|$ values.

It is also noteworthy that $W$. britannica and $W$. barnesiae differ in their susceptibility to dissolution (Pittet and Mattioli 2002). W. barnesiae has the most solid central area of all the Watznaueria species reported herein, and seems to be the most resistant one. Nevertheless, the similar $|\mathrm{R}|$ values for these species (or even higher for $W$. britannica) in their correlations with richness values indicate rather the minor influence of dissolution on their share in the studied material.

The best correlation is revealed for Watznaueria spp. and $B$. dubium $+S$. lumina $+Z$. erectus, with an almost perfect linear fit. As $W$. fossacincta shows no correlation to $B$. dubium $+S$. lumina $+Z$. erectus, it is clear that only $W$. britannica and $W$. barnesiae play a role in this fitting. It may be suggested that $B$. $d u$ bium $+S$. lumina $+Z$. erectus replace the ecological niche of $W$. britannica and $W$. barnesiae. Nevertheless, perfect linear regression with a negative slope between those two groups may be explained rather as a sign of selective dissolution than the effect of changes in ecological conditions. Such an explanation would be true if $W$. barnesiae, supposedly the most resistant species, had a high negative correlation to richness. Consequently, the rest of the Watznaueriacae should have a lower negative or no linear correlation. In fact, $W$. barnesiae has a lower negative $|\mathrm{R}|$ correlation to richness than $W$. britannica in the studied samples (Table 2). Therefore, evidence of strong selective dissolution cannot be confirmed in the studied sections.

In conclusion, the chosen variables show that $W$. britannica and $W$. barnesiae dominated in less diverse assemblages. This cause domination of W. britannica and $W$. barnesiae in the whole studied section. B. dubium, S. lumina and Z. erectus are more abundant in more diverse assemblages.

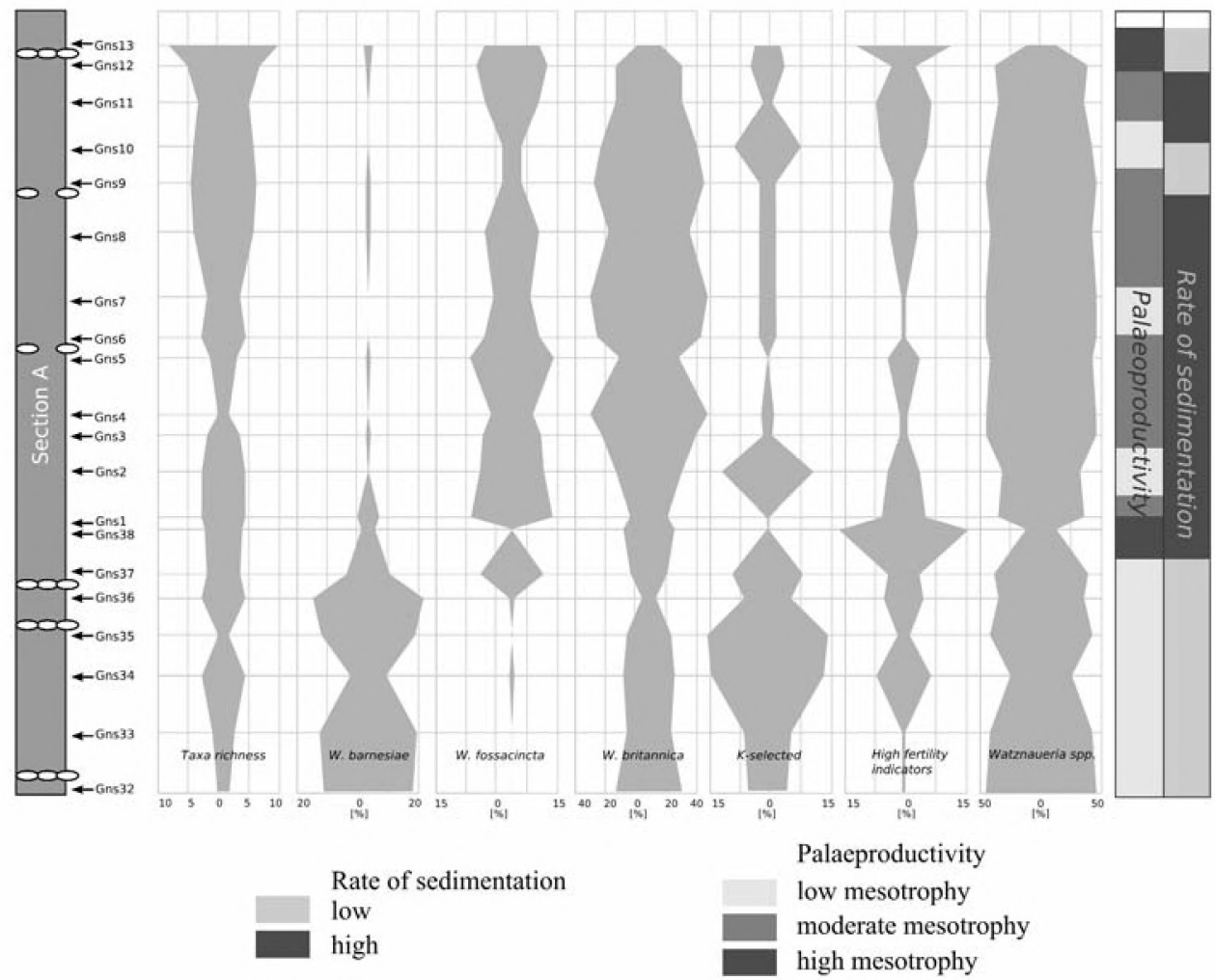


Factors controlling calcareous nannofossil productivity

Although the analysis of correlation coefficients provides important information on the general trends in the frequency distribution of the studied assemblages, its resolution does not enable appropriate palaeoenvironmental interpretation. Additional information is supplied by the frequencies of the nannofossil taxa in particular samples (Text-figs 8, 9).

The lowest species richness, less than 10 taxa, is recorded in the lower parts of sections A(Gns32-Gns7) and B (Gns14a-Gns17); in the Subcontractus, Morrisi and lower part of the Bremeri zones (Text-figs 2). The richest assemblages, more than 15 taxa, occur in the upper parts of sections A (Gns13) and C, above sample Gns26. The latter is also characterised by a high contribution of species regarded as good palaeofertility-indicators ( $Z$. erectus and $B$. dubium) and a higher abundance of S. lumina (in contrast to Watznaueria spp. which becomes rare) (Text-figs 7,8). Such occurrence of palaeofertility-indicators suggests a higher availability of nutrients in the surface water during deposition of the upper part of the succession, i.e., during the Retrocostatum Zone. Similarly, the samples taken from the interval around the $\mathrm{O}$ and $\mathrm{P}$ siderite horizons (Gns34, Gns38 and Gns16a) are also slightly enriched in $Z$. erectus and B. dubium.
This pattern of nannofossil distribution partially corresponds to the pattern of sediment grain-size as observed in the succession (Leonowicz 2012, this issue): the lowermost part of the succession, between the $\mathrm{N}$ and $\mathrm{O}$ siderite horizons (samples Gns14a, Gns33-35) is characterised by the highest content of sand, suggesting the proximity of the source area, entailing delivery of clastic material together with fresh-water, making the marine surface-water hostile for most of the calcareous nannoplankton. Coarse-grained sediments are usually indicative of high energy environments with a high rate of accumulation, but this feature is not essential. A high rate of sedimentation may also characterize fine-grained sediments. In the studied succession, the rate of sedimentation can be estimated based on the presence of horizons with siderite concretions. Most of the concretions are of early diagenetic origin and some of them underwent early reworking (hiatus concretions). They are considered as levels of low sedimentation rate (Majewski 2000; Witkowska 2012, this issue). Formation of the concretions requires stable conditions when the sedimentation rate had been significantly decreased (Witkowska 2012, this issue). This may produce surface-water condition favourable for calcareous nannoplankton (Textfigs $2,7,8$ ). The stable conditions occurring during concretion formation are evidenced by the enhanced occurrence of Ethmorhabdus gallicus and Pseudo-

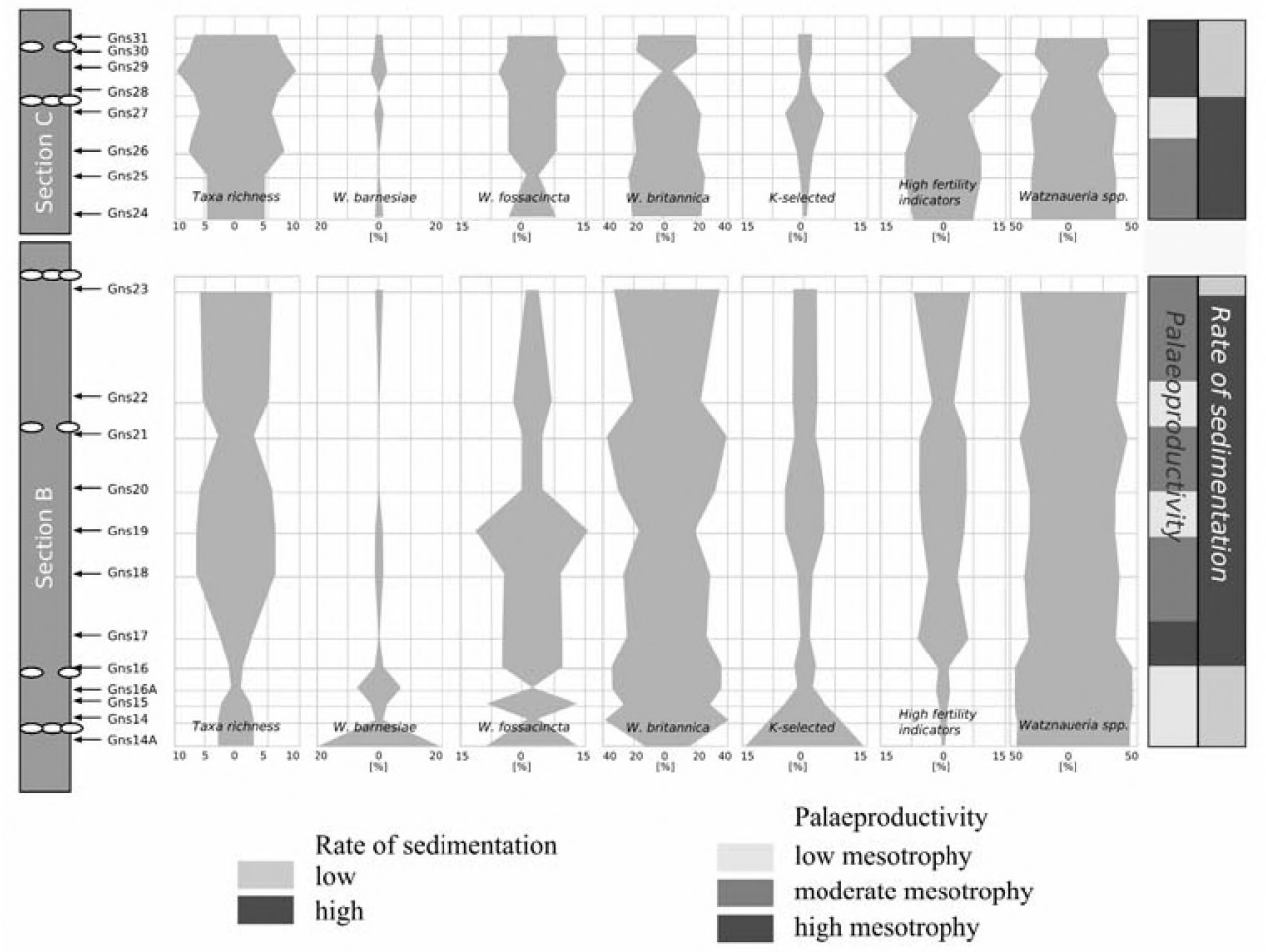

Text-fig. 9. Relative abundance of selected taxa or groups of taxa of calcareous nannofossils, with inferred palaeofertility and sedimentation rate in sections B and C 
conus enigma, which may be considered $K$-selected taxa. Their higher abundance is recorded in the lower part of sections A and B (around the concretion horizons $\mathrm{O}$ and $\mathrm{P}$ ) (see Text-figs 2, 8, 9). In this case, the more frequent occurrence of $K$-selected taxa can be explained by a low dynamic water environment (low rate of sedimentation) and relatively low concentration of nutrients. This can be related to the (oligotrophic?) low mesotrophic palaeoenvironments (Text-figs 8,9).

The middle part of the succession (generally between concretion horizons $P$ and S) dominated by clays and/or clayey shales and with rare concretion horizons, most probably originated during a relatively high rate of sedimentation (Majewski 2000). The nannofossil assemblages from this part of the succession are of low diversity and dominated by $W$. britannica. This relationship may be explained by the generally unstable ecological conditions during periods of a high rate of sedimentation, habitable only for $r$-selected taxa. A higher rate of clastic deposition was connected with higher nutrient supply and destabilization of the environmental conditions. These periods could have also been characterised by a decrease in salinity caused by fresh-water input.

The nannofossil record from the upper part of the succession most probably reflects the highest fertility of the sea surface-water as the fertility-indicating taxa have their peak of abundance. It should also be emphasised that the rate of nutrient supply (regardless of sedimentation rate) was constantly moderate or high, indicating a low to high mesotrophic environment. Consequently, it seems that it was mainly water dynamics (stable or unstable conditions) that controlled the composition of nannoplankton assemblages.

Based on estimated fertility and sedimentation rate, inferred from nannoplankton assemblages, the following palaeoenvironments may be distinguished (Textfigs 8,9 ):

- low mesotrophy and moderate (high?) rate of sedimentation (low frequency of palaeofertility indicators, high frequency of $\mathrm{K}$-selected taxa); middle part of the Gnaszyn succession (samples Gns2; 6? -7?; 10; 19 $20 ; 22 ; 27$ );

- low mesotrophy and low rate of sedimentation (dominance of Watznaueria spp. and high frequency of $K$ selected taxa); lower part of the Gnaszyn succession (samples Gns32-37; 14A-16A);

- mesotrophy and high rate of sedimentation (dominance of Watznaueria group); middle part of the Gnaszyn succession (samples Gns1; 3-5; 8-9; 11; 18; $21 ; 23-26$ )

- moderate/high mesotrophy with low rate of sedimentation (high frequency of palaeofertility indicators, low frequency of $K$-selected taxa, high diversity); upper part of the Gnaszyn succession (samples Gns12-13; 28-31)

\section{SUMMARY}

The Gnaszyn succession contains poorly to moderately preserved calcareous nannofossil assemblages dominated by species of Watznaueria (especially $W$. britannica).

Although diagenetic processes may have enriched the samples in dissolution-resistant species to some extent, the assemblages seem to have been only weakly affected by dissolution and still record their primary composition.

Watznaueria britannica and $W$. barnesiae dominate assemblages with low diversity. There is some offset in their abundance which complemented each other in their dominance throughout the entire material studied.

Biscutum dubium, Staurolithites lumina and Zeugrhabdotus erectus are more abundant in assemblages with higher diversity and show the opposite trend in abundance to $W$. britannica and $W$. barnesiae.

Pseudoconus enigma and Ethmorhabdus gallicus may represent $K$-selected species.

The palaeoenvironment of sedimentation of the studied deposits may represent low through moderate/high mesotrophy. The unstable rate of sedimentation and nutrient supply (thus palaeoproductivity) together with changes in stability of the surface water dynamics were the main factors controlling the frequency of the taxa throughout the succession and the diversity of the assemblages. These factors most probably reflected climatic and/or bathymetric changes regulated by proximity of the coastline and/or the amount of the river-derived input.

The high amount of suspended organic matter reduces light availability so that only opportunistic species can survive in such conditions. Interruption or decrease in the rate of sedimentation and simultaneous high nutrient supply (a predominant mesotrophic palaeoenvironment) improved the ecological conditions, causing a decrease in the percentage of $r$-selected taxa and an increase in the diversity of the assemblages. On other hand, a low rate of sedimentation and low nutrient supply is reflected in an increase in abundance of $K$-selected taxa. 


\section{Acknowledgements}

I thank Przemyslaw Gedl for delivering the rock samples and motivating me to study this subject. I am very grateful to Fabienne Giraud for her very constructive remarks improving the text and completing the reference list, and to Katarina Holcova for her inspiring suggestions. Special thanks go to Andrzej Kaim for his remarkable comments and suggestions. This text has greatly benefited from comments and corrections by Ireneusz Walaszczyk. The paper is a contribution of the Jagiellonian University Institute of Geological Sciences BW fund and DS project No 001673.

\section{REFERENCES}

Andruleit, H., Stäger, S., Rogalla, U. and Čepek, P. 2003. Living coccolithophores in the northern Arabian Sea: ecological tolerances and environmental control. Marine $\mathrm{Mi}$ cropaleontology, 49, 157-181.

Balch, W.M. 2004. Re-evaluation of the physiological ecology of coccolithophores. In: Coccolithophores. In: H.R. Thierstein and J.R Young (Eds), From Molecular Processes to Global Impact, pp. 165-190. Springer; Berlin, Heidelberg, New York.

Billard, C. and Inouye, I. 2004. What is new in coccolithophore biology? In: H.R. Thierstein and J.R. Young (Eds), Coccolithophores. From Molecular Processes to Global Impact, pp. 1-29. Springer; Berlin, Heidelberg, New York.

Burnett, J.A., Young, J.R. and Bown, P.R. 2000. Calcareous nannoplankton and climate change. In: S.J. Culver and P.F. Rawson (Eds), Biotic Response to Global Change. The Last 145 Milion Years, pp. 35-50. Cambridge University Press; Cambridge, New York, Melbourne.

Bown, P.R. 1987. Taxonomy, biostratigrapy, and evolution of late Triassic-early Jurassic calcareous nannofossils. Special Papers in Palaeontology, 38, 1-118.

Bown, P.R. and Cooper, M.K.E. 1998. Jurassic. In: P.R. Bown (Ed.), Calcareous Nannofossil Biostratigraphy, pp. 34-85. Kluwer Academic Publishers; Dordrecht, London, Boston.

Bown, P.R., Burnett, J.A. and Gallagher, L.T. 1992. Calcareous nannoplankton evolution. Memorie di Scienze Geologiche già Memorie degli Istituti di Geologia e Mineralogia dell'Universita di Padova, 43, 1-17.

Bown, P.R., Lees, J.A. and Young, J.R. 2004. Calcareous nannoplankton evolution and diversity through time, In: H.R. Thierstein and J.R. Young (Eds), Coccoltihophores. From Molecular Processes to Global Impact, pp. 481-508. Springer; Berlin, Heidelberg, New York.

Bown, P.R. and Young, J.R. 1998a. Introduction. In: P.R. Bown (Ed.), Calcareous Nannofossil Biostratigraphy, pp.
1-15. Kluwer Academic Publishers; Dordrecht, London, Boston.

Bown, P.R. and Young, J. R., 1998b. Techniques. In: P.R. Bown (Ed.), Calcareous Nannofossil Biostratigraphy, pp. 16-28. Kluwer Academic Publishers; Dordrecht, London, Boston.

Brand, L.E. 1994. Physiological ecology of marine coccolithophores. In: A. Winter A. and W.G. Siesser (Eds), Coccolithophores, pp. 39-50. Cambridge University Press; Cambridge.

Brummer, G.J.A. and Van Eijden, A.J.M. 1992. 'Blue-ocean' paleoproductivity estimates from pelagic carbonate mass accumulation rates. Marine Micropaleontology, 19, 99117.

Carcel, D., Colombié, C., Giraud, F. and Courtinat, B. 2010. Tectonic and eustatic control on a mixed siliciclastic-carbonate platform during the Late Oxfordian-Kimmeridgian (La Rochelle platform, western France). Sedimentary Geo$\log$, 223, 334-359.

Erba, E. 1992. Middle Cretaceous calcareous nannofossils from the western Pacific (Leg 129): evidence for paleoequatorial crossing. Proc. ODP, Scien. Results, 129, 189201.

Falkowski, P.G., Schofield, O., Katz, M.E., Van de Schootbrugge, B. and Knoll, A.H. 2004. Why is the Land Green and the Ocean Red? In: H.R. Thierstein and J.R. Young (Eds), Coccoltihophores. From Molecular Processes to Global Impact, pp. 427-453. Springer; Berlin, Heidelberg, New York.

Gedl, P. and Kaim, A. 2012. Palaeoenvironmental reconstruction of Bathonian (Middle Jurassic) sediments at Gnaszyn, Kraków-Częstochowa Upland, Poland - introduction. Acta Geologica Polonica, 62 (3), 267-280.

Gedl, P., Kaim, A., Boczarowski, A., Kędzierski, M., Smoleń, J., Szczepanik, P., Witkowska, M. and Ziaja, J. 2003. Rekonstrukcja paleośrodowiska sedymentacji środkowojurajskich iłów rudonośnych Gnaszyna (Częstochowa) wyniki wstępne. Tomy Jurajskie 1, 19-27. [In Polish]

Giraud, F. 2009. Calcareous nannofossil productivity and carbonate production across the Middle-Late Jurassic transition in the French Subalpine Basin. Geobios, 42, 699714.

Giraud, F., Pittet, B., Mattioli, E. and Audouin, V. 2006. Paleoenvironmental controls on the morphology and abundance of the coccolith Watznaueria britannica (Late Jurassic, southern Germany). Marine Micropaleontology, 60 , 205-225.

Giraud, F., Courtinat, B. and Atrops, F. 2009. Spatial distribution patterns of calcareous nannofossils across the Callovian-Oxfordian transition in the French Subalpine Basin. Marine Micropaleontology, 72, 129-145.

Hammer, Ø., Harper, D.A.T. and Ryan, P.D. 2001. Past: Paleontological Statistics Software Package for Edu- 
cation and Data Analysis. Palaeontologica Electronica, 4, $9 \mathrm{pp}$. http://palaeo-electronica.org/2001_1/past/issue 1 01.htm

Herrle, J. O. 2003. Reconstructing nutricline dynamics of mid-Cretaceous oceans: evidence from calcareous nannofossils from the Niveau Paquier black shale (SE rance). Marine Micropaleontology, 47, 307-321.

Hill, M.E. 1975. Selective dissolution of mid-Cretaceous (Cenomanian) calcareous nannofossils. Micropaleonto$\log , 21,227-235$.

Kaim, A. 2004. The evolution of conch ontogeny in Mesozoic open sea gastropods. Palaeontologia Polonica, 62, $3-$ 183.

Kaim, A. 2008. A review of gastropods from a Callovian (Middle Jurassic) glacial drift at Łuków, Eastern Poland. Neues Jahrbuch für Geologie und Paläontologie $A b$ handlungen, 247, 161-176.

Kaim, A. 2011. Non-actualistic wood-fall associations from Middle Jurassic of Poland. Lethaia, 44, 109-124.

Lampert, L., Queguiner, B., Labasque, T., Pichon, A. and Leberton, N. 2002. Spatial variability of phytoplankton composition and biomass on the eastern continental shelf of the Bay of Biscay (north-east Atlantic Ocean). Evidence fro a bloom of Emiliania huxleyi (Prymnesiophyceae) in spring 1998. Continental Shelf Research 22, 1225-1247.

Lees, J.A., Bown, P.R., Young, J. R. and Riding, J. B. 2004. Evidence for annual records of phytoplankton productivity in the Kimmeridge Clay Formation coccolith stone bands (Upper Jurassic, Dorset, UK). Marine Micropaleontology, 52, 29-49.

Lees, J.A., Bown, P.R. and Mattioli, E. 2005. Problems with proxies? Cautionary tales of calcareous nannofossil palaeoenvironmental indicators. Micropaleontology, 51, 333-343.

Lees, J.A., Bown, P.R. And Young, J.R. 2006. Photic zone palaeoenvironments of the Kimmeridge Clay Formation (Upper Jurassic, UK) suggested by calcareous nannoplankton palaeoecology. Palaeogeography, Palaeoclimatology, Palaeoecology, 235, 110-134.

Leonowicz, P. 2012. Sedimentology and ichnology of Bathonian (Middle Jurassic) orebearing clays at Gnaszyn, Kraków-Silesia Homocline, Poland. Acta Geologica Polonica, 62 (3), 281-296.

Majewski, W. 2000. Middle Jurassic concretions from Częstochowa (Poland) as indicators of sedimentation rates. Acta Geologica Polonica, 50, 431-439.

Mattioli, E. and Pittet, B. 2002. Contribution of calcareous nannoplankton to carbonate deposition: a new approach applied to the Lower Jurassic of central Italy. Marine Micropaleontology, 45, 175-190.

Matyja, B.A. and Wierzbowski, A. 2003. Biostratygrafia amonitowa formacji częstochowskich ilów rudonośnych (naj- wyższy bajos - górny baton) z odsłonięć w Częstochowie. Tomy Jurajskie, 1, 3-6. [In Polish]

Matyja, B.A. and Wierzbowski, A. 2006. Stop B1.7 - Gnaszyn clay pit (Middle Bathonian-lowermost Upper Bathonian). Ammonite biostratigraphy. In: A. Wierzbowski et al. (Eds), Jurassic of Poland and adjacent Slovakian Carpathians, pp.154-155. Field trip guidebook of $7^{\text {th }}$ International Congress on the Jurassic System. Polish Geological Institute; Warszawa.

Okada, H. and Honjo, S. 1973. The distribution of oceanic coccolithophorids in the Pacific. Deep-sea Research, 20, 355-374.

Olivier, N., Pittet, B. and Mattioli, E. 2004. Palaeoenvironmental control on sponge-microbialite reefs and contemporaneous deep-shelf marl-limestone deposition (Late Oxfordian, southern Germany). Palaeogeography, Palaeoclimatology, Palaeoecology, 212, 233-263.

Painter, S.C., Poulton, A.J., Allen, J.T., Pidcock, R. and Balch, W.M. 2010. The COPAS'08 expedition to the Patagonian Shelf: Physical and environmental conditions during the 2008 coccolithophore bloom. Continental Shelf Research, 30, 1907-1923.

Perch-Nielsen, K. 1985. Mesozoic calcareous nannofossils. Cenozoic calcareous nannofossils. In: H.M. Bolli, J.B. Saunders and K. Perch-Nielsen (Eds), Plankton stratigraphy, pp. 329-554. Cambridge University Press, Cambridge.

Pianka, E. R. 1970. On r- and K-Selection. American Naturalist, 102, 592-597.

Pittet, B. and Mattioli, E. 2002. The carbonate signal and calcareous nannofossil distribution in an Upper Jurassic section (Balingen - Tieringen, Late Oxfordian, southern Germany). Palaeogeography, Palaeoclimatology, Palaeoecology, 179, 71-96.

Rost, B. and Riebesell, U. 2004. Coccolithophores and the biological pump: responses to environmental chnages, In: H.R. Thierstein and J.R. Young (Eds), Coccoltihophores. From Molecular Processes to Global Impact, pp. 99-125. Springer, Berlin, Heidelberg, New York.

Roth, P. H. 1983. Jurassic and Lower Cretaceous calcareous nannofossils in the western North Atlantic (Site 534): biostratigraphy, preservation, and some observations on biogeography and palaeoceanography. Initial Reports of the Deep Sea Drilling Project, 76, 587-621.

Roth, P. H. 1986. Mesozoic palaeoceanography of the North Atlantic and Tethys Oceans. In: C.P. Summerhayes and N.J. Shackleton (Eds), North Atlantic Palaeoceanography, Geological Society, London, Special Publication, 21, 299320.

Roth, P. H. and Bowdler, J. L. 1981. Middle Cretaceous calcareous nannoplankton biogeography and oceanography of the Atlantic and Indian oceans. SEPM Special Publications, 32, 517-546. 
CALCAREOUS NANNOFOSSILS FROM MIDDLE JURASSIC ORE-BEARING CLAYS

Roth, P.H. and Krumbach, K.R. 1986. Middle Cretaceous calcareous nannofossil biogeography and preservation in the Atlantic and Indian Oceans: Implications for paleogeography. Marine Micropaleontology, 10, 235-266.

Street, C. and Bown, P.R. 2000. Palaeobiogeography of Early Cretaceous (Berriasian-Barremian) calcareous nannoplankton. Marine Micropaleontology, 39, 265-291.

Thierstein, H.R. 1980. Selective Dissolution of Late Cretaceous and Earliest Tertiary Calcareous Nannofossils: Experimental Evidence. Cretaceous Research, 2, 165-176.

Thierstein, H.R., Geitzenauer, K.R. and Molfino, B. 1977. Global synchroneity of Late Quaternary coccolith datum levels: validation by oxygen isotopes. Geology, 5, 400-404.

Thomsen, E. 1989. Seasonal variation in boreal early cretaceous calcareous nannofossils. Marine Micropaleonto$\log y, 15,123-152$.

Manuscript submitted: 01 ${ }^{\text {st }}$ August 2010

Revised version accepted: $31^{\text {st }}$ August 2012
Watkins, D.K. 1989. Nannoplankton productivity fluctuations and rhythmically-bedded pelagic carbonates of the Greenhorn Limestone (Upper Cretaceous). Palaeogeography, Palaeoclimatology, Palaeoecology, 74, 75-86.

Winter, A., Jordan, R.W. and Roth, P.W. 1994. Biogeography of living Coccolithophores in oceanic waters. In: A. Winter and W.G. Siesser (Eds), Coccolithophores, pp. 161177. Cambridge University Press; Cambridge.

Witkowska, M. 2012. Palaeoenvironmental significance of iron carbonate concretions from Middle Jurassic of Gnaszyn (Polish Jura Chain, southern Poland). Acta Geologica Polonica, 62 (3), 307-324.

Young, J.R. 1994. Functions of coccolith. In: A. Winter and W.G. Siesser (Eds), Coccolithophores, pp. 63A. Winter and W.G. Siesser (Eds), Coccolithophores, pp. 82. Cambridge University Press; Cambridge. 